Research:

\title{
THE EFFECT OF TAX MORALITY, TAX CULTURE, AND GOOD GOVERNANCE TO TAXPAYERS COMPLIANCE
}

\author{
By: \\ INDAR KHAERUNNISA \\ ADI WIRATNO \\ ELVIRA LUTHAN \\ e-mail: indar.khaerunnisa@danone.com, adiwiratno08@yahoo.com, \\ vira.luthan@gmail.com
}

\begin{abstract}
This study aims to determine how the effect of the tax morality of the level of participation of citizens, the confidence level, the level of local autonomy, national pride, demographic factors, economic conditions, deterrence factors, and the tax system to tax compliance. how cultural influences taxes consist of the respondents to react to the tax culture is a relationship between the tax authorities and the taxpayer, tax regulations and the national culture of tax compliance. how the influence of good governance such as human resources, information technology, organizational structure, processes and procedures as well as financial resources and incentives for tax compliance of corporate entities registered in the National Construction Contractors Association of Indonesia. Data obtained by sending a questionnaire to the members of the Bogor City GAPENSI 80 respondents with data analysis using Partial Least Square (PLS). Hypothesis testing results show that the path coefficient relationship between tax morality of compliance of tax of 0.3655 and the value of $t$-statistic of 3.0149 (> 1.96), testing hypotheses for testing the path coefficient relationship between culture variable tax on tax compliance at 0.2352 and the value of $t$-statistic of $2.1832(>1.96)$, and the third hypothesis testing path coefficient value of the relationship between good governance on tax compliance by 0.2983 with a t-statistic values of 2.5984 (>1.96).
\end{abstract}

Keywords: Tax Morality,Tax Culture, Good Governance, Compliance of Taxpayer

Research on tax compliance previously performed by Widodo (2010) uses a variable tax morality, and culture as an independent variable tax and tax compliance as the dependent variable. The study was conducted with 480 respondents to the survey method taxpayer in six major cities in Indonesia, namely Jakarta, Makassar, Medan, Surabaya, Yogyakarta and Bandung. The respondents were those aged 17 years and over whoselected through random systematic methodology.

Inspired by these studies, the authors are interested in creating a replication of the study, the form of replication made by the author, namely in terms of the dependent and independent variables. The independent variables used is tax morality and tax culture and the dependent variable using taxpayer compliance, but then I added other independent variables, namely good governance, it was done because based on the research that good governance is a variable can affect tax compliance (Theresia, 2009), Respondents in the study of Widodo was respondents aged 17 years and above were selected through random systematic methodology, while for this study the authors use is taxpayer GAPENSI member of Bogor. The author is very interested in conducting this research back as previous writers had joined as a member GAPENSI Bogor, based on observations over a member of the many things you encountered regarding tax compliance member that is very unique. Respondents became more interesting to study because GAPENSI as construction and procurement business associations in Bogor, where almost all corporate taxpayers who participate in the procurement and construction activities in Bogor shall be a member in this association. It is making it increasingly attractive because $64 \%$ resulting tax revenues in Bogor city received comes from corporate taxpayers, where $83 \%$ of income tax payers The bodies came from the construction sector and procurement (Iskandar, 2012). 
Regarding the tax culture, the economy in general there is little empirical evidence and experiments to discuss the influence of culture. In the area of tax compliance, cross-cultural studies is new and latest research binding tax reporting relevant factor is constant, and therefore can be better binding factor of the cultural differences that may occur. Based on the above, some of the principal issues to be discussed further in the final work is as follows:

How to influence the tax morality of the level of citizen participation, the confidence level, the level of local autonomy, national pride, demographic factors, economic conditions, deterrence factors, and the tax system to tax compliance?

How to influence the tax culture consists of the respondents to react to the tax culture is a relationship between the tax authorities and the taxpayer, tax regulations and the national culture of tax compliance?

How to influence good governance in the form of human resources, information technology, organizational structure, processes and procedures as well as financial resources and incentives to tax compliance?

\section{LITERATURE REVIEW}

Theory applied in this research is using agency theory where this theory assumes that the principal and the agent is the economic actors are rational thinking and actions solely for personal purposes, but they find it difficult to distinguish the difference on preference, trust and information. Conflicts of interest that later emerged between the principal and the agent which caused the agency relationship is a contract where the parties principal rule the other person (the agent) to perform a service on behalf of the principal and authorizes the agent to provide the best decisions for the principal (Jensen, 2012).

In this study the principal is intended by the government / state has the right to levy taxes on the citizens, in the interest of national development. The amount of development costs to be borne by the state / government to encourage them to optimize the withholding tax, by picking what indeed they are entitled under the rules and regulations of taxation. Agents referred to in this article are those taxpayers who undergo a self-assessment, they are the ones who should see to it that the central government objectives can be achieved, namely to optimize tax collection. In the next step if both parties have the same vision, namely to optimize the tax, it is expected that the agent will act in accordance with the interests of the principal.

Taxes are a source of sustainable funding for the construction, the tax is also the liaison between the state and its citizens, while tax revenue is the lifeblood of the social contract government and their communities, where the social contract is the choice of social or collective choice on the provisions of the fulfillment of public goods and services for society as payoff from tax payments (Ayee, 2008). Principal elements of the above definition, namely: dues or charges, levied under the Act, the tax may be imposed, does not receive or obtain contra, and to finance spending general government (Nurmantu, 2003).

Tax morality can be defined as intrinsic motivation to pay taxes arising from the moral duty or confidence to contribute to the country by paying taxes (Torgler, 2003). Tax morality does not measure individual behavior, but rather the attitude and the individual. This can be seen as a moral obligation to pay taxes, the conviction of contributing to society by paying taxes. Indicators of tax morality, among others: the level of citizen participation, the confidence level, the level of autonomy or decentralization, demographic factors, economic conditions, national pride, deterrent and taxation system.

Tax culture in which the classical concept of tax culture of a country is closely related to the personality shown by the evolution of a system of taxation. Investigated the tax culture among taxpayers and tax offices. In their view, the problems occurred between "doing guidance on compensation in connection with a breach of work by the tax authorities: and" to contribute to the culture of tax through tax disputes ". so in this case, the tax culture is characterized by the relationship between the tax authorities to the taxpayer and behavioral patterns that arise from the relationship (llyas and Burton, 2007). There are three things that affect the tax culture among others: the relationship between tax officials and taxpayers, tax regulations, the national culture.

Tax compliance means that the taxpayer has a willingness to meet their tax obligations according to the rules without the need to hold the examination, thorough investigation warning, or threat of sanctions and the application of legal or administrative (Gunadi, 2012). Compliance fulfill

Indar Khaerunnisa, Adi Wiratno, and Elvira Luthan: The Effect of Tax Morality, Tax Culture, and Good Governance to Taxpayers Compliance 
tax obligations voluntarily form the backbone of the self-assessment system, in which the taxpayer is responsible for setting tax obligations and then accurately and timely pay and report the tax. Indicators of tax compliance among others: formal compliance, compliance material. formal compliance is a kind of obedience which the taxpayer limited to meet the tax provisions. more material compliance within its scope, namely compliance with the letter and spirit substantive tax provisions.

\section{RESEARCH METHOD}

The method used in this research is descriptive research, where descriptive research method is a method of research that is widely used in research that aims to explain an event. This research is associative, done by connecting one variable with another variable in order to determine, explain and predict the level of dependence of the independent variables and the dependent variable. In its implementation of data collection by survey or questionnaire. The unit of analysis is the study of individuals, ie individuals who are businessmen construction incorporated in GAPENSI are only collected once at a particular time also called Cross-sectional (Supriyanto, 2011). Analysis of the data in this study using Partial Least Square (PLS). PLS can be used on any scale of data (nominal, ordinal, interval, ratio) and assuming a more flexible terms. PLS is also used to measure the relationship of each indicator with its constructs. Additionally, the PLS can test the structural model bootstrapping are outer and inner models models. Because in this study using indicators to measure each construct it, and also the measurement model is structural, it was decided to use PLS. PLS can be used for confirmation purposes, such as hypothesis testing and exploration purposes. But prefers PLS as an exploration rather than a confirmation. But the main purpose of the PLS is to explain the relationship between a construct and emphasizes the notion of the value of the relationship. The important thing to note is the necessity of theories presume to describe the model, variable selection, analytical approach, and interpretation of results (Yamin, 2011).

\section{RESULTS AND DISCUSSION}

Model measurement is a model that specifies the relationship between the latent variables with the indicators or it can be said that the outer model defines how each indicator relates to its variable constructs. There are four latent constructs that Tax Morale, Good Governance, Tax Culture and Tax Compliance. Indicators on the construct of Tax Morale, Tax Culture and Tax Compliance are formative while indicators on the construct of Good Governance reflective construct.

Variables good governance demonstrate the validity converge for indicators of transparency $0.9281,0.8903$ human resources, organizational structure and information technology 0.9231 0.9391 can be said that the indicator has a good convergent validity because it has exceeded the limit values loading $>0.5$. Then tested the discriminant validity where the measurement model assessed by measurement of cross loading the construct. If the correlation construct with each indicator is larger than the other construct, then the latent construct the indicator predicts better than any other construct. The results show that sub variable transparence. Human Resources, Organizational Structure and information technology is an indicator fitted as a construct of good governance, as it has the greatest value than the other variables. It consists of the transparency of $0.9281,0.8903$ human resources, organizational structure 0.9231 , and 0.9391 of information technology. And then added variable of good governance has reached a good discriminant validity. That's because the AVE value $>0.5$ is equal to 0.8470 . In addition to achieving number $>0.8$ is 0.9567 for composite reliability. It can be said that a construct has a high reliability. For testing with PLS, reliability testing reinforced by the Cronbach'sapha where consistency every the answer was tested with Cronbach's alpha achieved $\alpha \geq 0.5$ is 0.9396 .

In the formative measurement, to measure the quality of a formative model of reliability indicators are evaluated by looking at the weight indicator values $>0.2$ or significant $t$ test. The significance criteria t test with an alpha value of $5 \%$ of the value $t=1.96$ and $10 \%$ of the value $t=$ 1.640 , but if the only indicator that showed significant weight indicator may still be maintained (Hair, 2011). The results of reliability test on latent constructs with formative indicators is as follows

Indar Khaerunnisa, Adi Wiratno, and Elvira Luthan: The Effect of Tax Morality, Tax Culture, and Good Governance to Taxpayers Compliance 
for variable tax morality, sub variable that support them are demographic factors with weight 0.2922 and t-statistics of 1525, for a level of trust with weight 0.2126 and t-statistics 1602, to the level of local autonomy by 0.3813 and t-statistics 1992, to the level of participation of citizens by weight 0.2271 and $1.634 \mathrm{t}$ statistic. Reliability test results variable tax culture by national cultural sub variables with weight 0.310 and t statistic of 1598 , relations the state apparatus and citizens with weight t-statistic 0.485 and 2.332, and government regulations by weight of t-statistic 0261 and 1301 . And the reliability test results for tax compliance with sub variable formal compliance with weight 0.6781 and t-statistic 5.155 and material compliance with weight 0.3822 and $\mathrm{t}$ 2621 statistics.

Then testing the relevance of prediction (Q2) aims to measure how well the observed values generated by the model and parameter estimation also shows the yield at 0.8470 is greater than zero which indicates that the model has good predictive relevance.

Inner model is a model that specifies the relationship between latent variables or can be said to describe an inner latent variable models based on the substance of the theory. Inner assess the model is to evaluate the relationship between latent variables as has been hypothesized in the study. R-square values for tax compliance showed a value of 0.699. R-square value means indicates that the variable tax morality, tax culture and Good Governance, was able to explain the variance tax compliance of $69.9 \%(0.699 \times 100 \%)$. the ability to explain the R-square value of 0.699 in the category of strong R-square value.

In the first hypothesis, a variable tax morality is exogenous latent variables affecting tax compliance as an endogenous variable. By comparing the test value $t$ with t-table $(=0.05)$, amounting to 1.96 then obtained the conclusion that all of the parameter estimates on the path diagram is significant because the value of the $t$-value $>0.05$. This means that there are significant tax morality on tax compliance, where the level of tax compliance significantly and positively influenced by the level of tax morality. The influence of the tax morality on tax compliance is equal to $36.55 \%$ where the largest contribution is obtained from the dimensions of regional autonomy level that is equal to $38.13 \%$ and the smallest contribution is obtained from Confidence at $21: 26 \%$.

The literature indicates that the phenomenon willingness taxation taxpayers to make their tax obligations is often referred to as "puzzle of tax compliance" (Torgler, 2007). This is because of the many factors that attempt to explain the fundamental question why taxpayers pay taxes. Social norm of tax compliance is a tax morality and tax morality is why taxpayers are willing and obedient to their tax liabilities. Results of research and research today has done much to support the relationship between the tax morality on tax compliance. Tax morality of individuals affected directly by the taxpayer will be their perception of the fulfillment of public goods and services by the State (James and Gomez, 2008). Furthermore, the higher the fiscal ability of the infringement, in the sense that there is a high economic cost to the tax obligations, the lower intrinsic motivation of individuals to pay taxes. This is in line with the results of research in which the fulfillment of public goods and services as well as high economic costs are part of the indicators of the level of public trust in government. However, the indicator turned out to have the lowest impact on tax morality and compliance in Bogor.

In the second hypothesis, the tax is a cultural variable exogenous latent variables affecting tax compliance as endogenous latent variables. By comparing the value of the $t$ test with t-table value $(=0.05)$, amounting to 1.96 it could be concluded that all of the parameter estimates on the path diagram is significant because the value of the t-value $>0.05$. this means that there are significant tax culture on tax compliance, where the level of tax morality significantly and positively influenced by the level of tax culture. Great influence of tax cultural on tax compliance by 23:52\%, of which the largest contribution is obtained from the dimensional relationship between the taxpayer and the Tax Reform that is equal to $48.48 \%$ and the smallest contribution obtained from the Tax Regulation that is equal to $26.15 \%$.

Variable tax culture have a smaller effect (23:52\%) on tax compliance than tax morality (36.55\%). This could be due to the apathy of both the government and taxpayers to promote tax culture. Tax culture is a set of good interaction includes the taxpayer, government, national culture and the rules of taxation. The taxpayer is generally felt that the tax is a burden, and the incentive of the contribution made tax payments can't be directly enjoyed where the government's responsibility to provide the fulfillment of public goods and services whose quality is doubtful. (Pandey, 2003). While the government generally issued policies and regulations without continuous dissemination and publication, so that there is a gap between the government and the taxpayer in this case. 
In the third hypothesis, good governance is a variable exogenous latent variables affecting tax compliance as endogenous latent variables. By comparing the value of the $t$ test with t-table value $(=0.05)$ of 1.96 it could be concluded that all of the parameter estimates on the path diagram is significant because the value of the t-value $>0.05$. this means that there is the effect of good governance on tax compliance, where the level of tax morality significantly and positively influenced by the level of tax culture. Great effect of good governance on tax compliance by $29.83 \%$, of which the largest contribution is obtained from the dimensions of the Information Technology by $28.63 \%$ and the smallest contribution is obtained from the Resource amounting to $26.39 \%$.

The test results show there is influence of variable Good Governance on four indicators ie Human Resources, Information Technology, Organizational Structure and Transparency. This result proves that the Information Technology becomes very important in the implementation of Good Governance. Information technology in a government supporter in the activities of taxation, be it from the perspective of the service, to increase its speed of development, is one of the drivers of the objectives of good governance. So it can be built a network of cooperation is based on relationships that are participatory, transparent, and responsive to the pillars of good governance. The use of information technology by the government, which allows the government to transform relationships with communities, businesses and interested parties to help the government and the provision of public services in order to better orientedcommunity service.

Conceptually, information technology is creating interactions were friendly and cost between the government and the people, because in practice of information technology as facilities and communication to the government's implementation of efficient and cheap, with improving public services by providing public means making it easy to get information, and create good governance and the establishment of government more accountable to its citizens. Given this information technology will create better government, because the service process more transparent, happening community control more powerful, and supervision that is attached to the time, reduction in corrupt practices, because the computer does not have innate behaviors that corrupt, Tata relationship leaner for the implementation of better government, increase government efficiency in all processes to deal with wasteful public sector spending or inefficiencies in various processes, there will be efficiency in space and time scales, the structure and organization of information that systematic and improved management of resources both in terms of the increase in the field of control and resourcespower organization.

Significant influence on the Good Governance Transparency is a principle that guarantees access or the freedom for everyone to obtain information about government administration, information on policies, the process of making and implementation and the results achieved. In addition, the information on every aspect of government policy that are accessible to the public. Disclosure of information is expected to produce healthy political competition, tolerant, and policies are based on public preferences. This principle has two aspects, namely the public communication by the government, and the public's right to information access. Both will be very difficult to do if the government does not deal well performance. Good performance management is the starting point of transparency. Public communication requires affirmative efforts of the government to disclose information and relevant activities. Transparency must be balanced with the need for confidentiality of institutions and information that affect individual privacy rights. Because the government produces large amounts of data, it needed professional information officer, not to make excuses for the government's decision, but to disseminate the decisions that are important to the community and explain each of these policies. The role of media is also very important for government transparency, both as an opportunity to communicate to the public and explain a variety of relevant information, as well as a "watchdog" over government actions and behavior deviates from the bureaucratic apparatus. Obviously, the media will not be able to perform this task without the freedom of the press, free from government intervention and influence of business interests.

Openness brings the consequence of excessive control of society and even by the mass media. Therefore, the obligation for transparency must be balanced with the value of the restrictions, which include clear criteria of public officials about what information they provide and to whom the information is given.

In summary it can be stated that the principle of transparency can be measured through a number of indicators such as: ensuring a system of openness and standardization of all processes of public services, facilitating the questions the public about various policies and public services, as

Indar Khaerunnisa, Adi Wiratno, and Elvira Luthan: The Effect of Tax Morality, Tax Culture, and Good Governance to Taxpayers Compliance 
well as processes in the public sector, facilitating reporting and dissemination of information as well as irregularities in the actions of public officials serving activities.

Openness of government on various aspects of public services, will eventually make the government accountable to all stakeholders with an interest in the process and activities in the public sector.Good Governance a significant influence on changes in the organizational structure. The main problem in the structure of the organization is to convince ourselves that the decisionmaking and accountability of all parties interested in the organization have the information and knowledge that is relevant to make good decisions and right and incentives commensurate who use the information in a productive and reliable, due to the environmental changes that influence the change organizational structure, costs, and benefits directly or indirectly should be analyzed carefully and cautiously. Given the effectiveness of the Good Governance function in organization structure can function properly. Then in the framework of the implementation of Good Governance, the structure of the modern organization can do: High awareness of the level of urgency, teamwork is good in the order of the staff and management, can create and communicate a vision, mission and programs, empowering all employees with regard interest and flair, giving the delegation of authority effectively, reducing unnecessary dependence, and develop organizational culture that is adaptive andthe use of performance analysis.

Good Governance a significant influence on human resources. The quality of human resources can be observed from the professionalism capability in accordance with the tasks they are responsible. Some factors that may affect human resources such as the level of education, training, and deployment of staff in the office. In the execution of duties, the principles of good governance contained in a reference to the implementation of government can work together with the community, in order to implement optimal public services. the attitude of government officials who commit irregularities in the administration and management of government may cause the results of development and public services largely as expected and planned. Thus the presence of qualified personnel who will be largely determined by the capacity of officials concerned to implement the principles of good governance in the administrationpublic service.

Good governance of the variables that most influence the result is information technology. Implementation of good governance will further optimize the role of information technology in various fields, because basically the use of information technology in general aims to facilitate the implementation of business processes and improve the competitive ability. In addition to the information technology operations of organizations can be implemented more easily, quickly, efficiently and effectively offered numerous opportunities for organizations to improve and transform production, service, market, work processes, and business relationships. However, there are still many companies and organizations that implement the principles and practices of good governance is not to optimize the role of information technology in implement when information technology is urgently needed in order to eliminate the shortcomings in the implementation of operational activities and services to customers inhibiting performance and process innovation and the company's business activities also Improved performance, competitive advantage, and the achievement of organizational goals and objectives can be achieved through the application of information technology and good governance.

There is the influence of the level of participation of the citizens against the morality of tax Indonesian citizens who are Muslim majority are accustomed to issuing compulsory contributions religious it being their foundation to participate in a tax obligation in each year, because according to their religious affiliation devout there are some good fortune belongs others who are in the treasures gained. Such thinking is also applicable in taxation, which found the treasure he earned them voluntarily aside for the good of others by supporting the government in the country's development. Therefore with the participation of citizens of this country will be formed morality taxes support the path of development.

There is the influence of the level of confidence in the formation of morality tax in this study found that the level of confidence in the government occupied the highest position, citizens are motivated to do the tax obligations due to the level of their confidence in the government that they believe with their revenues derived from this tax will help in development. In addition the level of trust is also comprised of confidence in the applicable law, that the law in this country can be enforced, also believes in the justice system. So that every form of crime will be rewarded in kind.Buoyed by the few examples of crimes that occur at this time who was later awarded sufficiently severe punishment. With the examples of such cases that make the deterrent effect against perpetrators of crimes and white collar also provides a good image for the government that

Indar Khaerunnisa, Adi Wiratno, and Elvira Luthan: The Effect of Tax Morality, Tax Culture, and Good Governance to Taxpayers Compliance 
the government does not mess around in performing its obligations, so that the mandate of the people in the form of tax payments also can be used for the people and notabused by those who intend to enrich themselves.

The influence of regional autonomy or decentralization on tax morality that is the presence of freedom in arranging Reviews their own government encourages citizens to further improve tax morality attitude. Because they think if there is freedom to self-government manages it can automatically monitor government receipts and expenditure derived from taxes, so as to increase of the intrinsic motivation to perform Reviews their tax obligations. In addition to the regional autonomy will occur more intensive relations between Compulsory Taxes and bureaucrats, as well as in the management of taxes they pay.

Pride factor influence on tax morality is to love someone of the Indonesian will create a sense of pride to be a citizen, so that the motivate reviews These factors can a person to always do good things for his country, Also ensure that the country can run well.

The influence of demographic factors on tax morality. Age, education, sex and marital status are things that could be causing the attitude thrusters to tax morality. The more mature age of a person, the higher a person's consciousness to their tax liabilities. Besides education can also foster intrinsic motivation for someone to do their tax obligations because the more knowledge that is received it will better understand the tax benefits for the country. This research also showed that women have a higher tax morality, although there is the woman who acted only as the wife then they will drive their husbands to do their tax obligations. As for marital status, many taxpayers who want to do the tax when already married, this is due to the marital status of any part of the tax to be paid has been separated from non-taxable income, which resulted in some parts of The revenue can be saved.

The relationship between tax officials with the taxpayer could be a relationship in the sense of an administrative nature related to the duties and responsibilities of tax officials to taxpayers, as well as informal relationships. Some of the things included in it, namely the hospitality officer, tax officer in a statement of capabilities tax problems, responsiveness and speed of the officers serving tax problems and attention attendantin serving tax problems.

Favorable tax rules will support the creation of a positive tax culture anyway. Tax provisions publicized through various media, the suitability of the implementation of tax administration by the tax officer with the applicable tax provisions to guarantee fairness while the taxpayer of taxation legal certainty of them that could affect intrinsic factors taxpayer.

The influence of national culture against the culture tax. Fundamental aspects to be indicators of the national culture that has a tendency towards the tax culture among other discipline problems of the nation. In Indonesia, the culture of tax and compliance is being pursued for intensified by the Directorate General of Taxes through programs of taxation imposed in Indonesia. This culture created by their belief in the benefits of the taxes paid.

For sub variable tax morality of eight factors that affect tax morality, only four had significant influence, namely demographic factors, pride factors, confidence level, and the level of citizen participation. The influence of tax moralityon tax compliance, where the level of tax compliance significantly and positively influenced by the level of tax morality. This is because of the many factors that attempt to explain the fundamental question why taxpayers pay taxes. Social norm of tax compliance is a tax morality and tax morality is why taxpayers are willing and obedient to their tax liabilities. Results of research and research today has done much to support the relationship between tax moralityon tax compliance. Research conducted in Bogor is also in line with previous research which claimed that one of the factors that affect tax compliance that demographic factors in the form of financial condition and taxpayers income.

The concept of tax culture is the whole formal and informal interactions within an institution that connects the national tax system with the practice of the relationship between tax officials with the taxpayer, which is historically attached to the national culture, including dependence and a bond formed as a result of ongoing interaction. Variable tax culture have a smaller effect (23:52\%) on tax compliance than tax morality (36.55\%). This could be due to the apathy of both the government and taxpayers to promote tax culture. The taxpayer is generally felt that the tax is a burden, and the incentive of the contribution made tax payments can't be directly enjoyed where the government's responsibility to provide the fulfillment of public goods and services quality is doubtful. Meanwhile, the government issued policies and regulations without continuous dissemination and publication, so that there is a gap between the government and the taxpayer. 
Information technology as a supporter of the government in the activities of taxation, be it from the perspective of the service, to increase its speed of development, is one of the drivers of the objectives of good governance. So it can be built a network of cooperation is based on relationships that are participatory, transparent, and responsive to the pillars of good governance. The use of information technology by the government, can transform the relationship with the community, the business world and interested parties can help and provision of public services in order to better and more service-oriented society. Conceptually, information technology is creating interactions were friendly and cost between the government and the people, because in practice of information technology as facilities and communication to the government's implementation of efficient and cheap, with improving public services by providing public means making it easy to get information, and create good governance and responsible for its citizens. Because of the service process more transparence, happening community control more powerful, and is closely monitoring the time, reduction in corrupt practices, in relationship management more streamlined, improved government efficiency in all processes of public sector spending, efficiency in space and time scales, structure and organization of information that systematic and improved management of resources both in terms of the increase in field control and resource organization.

In line with previous research which claimed that the efforts made by the tax authorities who are required to be able to accommodate people's desire to get good service, especially public services provided by the government, has made every effort to get the right solution, namely the implementation of good Governance on each service provided (Siagian, 2008). Implementation of good governance can be done well with the support of human resources and information technology systems that support the establishment of a modern administrative system. Human resources carefully prepared to support the tax administration reform with the implementation of modern tax administration system is one of the main agenda in the blue print DJP policy. The establishment of an organizational structure that is one-size-fits-all in determining public policy to create the principles of Good Governance which basically does not only depend on instrument approach organizational principle also included in it which should be effectively can take advantage of them in order to achieve the principle of compliance (Pamuk, 2008).

\section{CONCLUSION}

Based on the formulation of the problem and research objectives in writing this research, it can be concluded that the tax morality is intrinsic motivation to pay taxes arising from the moral duty or confidence to contribute to the country by paying taxes. Culture taxes is an overall formal and informal interactions within an institution that connects the national tax system with the practice of the relationship between the apparatus of tax by the taxpayer, which is historically attached to the national culture, including dependence and a bond formed as a result of ongoing interaction, and the adoption of good governance will further optimize the role of information technology for facilitating its business processes and improve the competitive ability.

\section{REFERENCES}

Ayee, Joseph R. A. 2008. Building Tax Compliance through Reciprocity with Government. University of Ghana, Legon.

B. Ilyas, Wirawan dan Richard Burton. 2007. Hukum Pajak. Salemba Empat: Jakarta

Gunadi, Prof. Dr. 2012. Keberhasilan Pajak Tergantung Partisipasi Masyarakatnya, dalam Perspektif Baru. http://www.perpsektif.net/articles/view.asp?id=431

Harinurdin, Erwin. 2009. Perilaku Kepatuhan Wajib Pajak Badan, Bisnis \& Birokrasi, Jurnal Ilmu Administrasi dan Organisasi, Mei-Agustus 2009, hlm 96-104 Volume 16, Nomor2.

Iskandar, Slamet. 2012. Sektor Jasa Penyumbang Terbesar Kota Bogor. Majalah investasi. James., I., Sanchez., dan Francisco Gomez. 2008. Economic and Non-economic Factors in Tax Compliance. KYKLOS, 48(1):8-18.

Indar Khaerunnisa, Adi Wiratno, and Elvira Luthan: The Effect of Tax Morality, Tax Culture, and Good Governance to Taxpayers Compliance 
Nurmantu, Safri. 2003. Pengantar Perpajakan, Jakarta, Kelompok Yayasan Obor, hal.1

Pandey,V. 2003., Relationship between Personality and Managerial Performance", Central Test Psychology International, www.centraltest.com/accessed on Mar02 2013.

Supriyanto. 2011. Pengantar Metodologi Penelitian Bisnis (revisi). Jakarta: Salemba Infotek.

Theresia, Rintha. 2009. Penerapan Good Governance pada Direktorat Jenderal Pajak, http://lontarui.ac.id

Torgler, Benno 2003. Tax Morale and Institutions, Center for Research in Economics, Management and The Arts, September 2003, hal.4.

Widodo, Widi. 2010. Moralitas, Budayadan Kepatuhan Pajak. CV Alfabeta, Jakarta.

Yamin, Sofyan. 2009. Generasi Baru Mengolah Data Penelitian dengan Partial Least

Square Path Modeling : Aplikasi dengan Software XLSTAT, Smart PLS, dan Visual PLS. Jakarta: Salemba Infotek. 
The Accounting Journal of BINANIAGA Vol. 01, No. 1, 2016

ISSN: 2527 - 4309

This page intentionally be emptied.

Indar Khaerunnisa, Adi Wiratno, and Elvira Luthan: The Effect of Tax Morality, Tax Culture, and Good Governance to Taxpayers Compliance

Page: 68 